\title{
Cameroon: Fonship and Power Politics in State Formation in Bafut
}

\author{
Divine Fuhnwi NGWA
}

\begin{abstract}
This work is an analysis of the strategies and methods used by a leader to wield power and maintain peace in a community prone to conflict, power and leadership crisis. The process of state formation or nation building in Africa has its own peculiarities. They differ from one community to the other depending on the practices of the people. The lifespan of the state also depends on the mechanism and strategies applied by the leader to manage conflicts encountered by his administration. In Bafut, traditional authority, governance and power politics revolve around the position of the Fon. He is at the head of a centralised polity made up of people from diverse origins speaking different languages. These people were brought together through conquest and assimilation by the ancestors of the Fon who succeeded in creating a ruling dynasty over the groups of people in the area. This led to the emergence of a complex political structure whose administration under the dynasty was suffocated by power tussles. Thus, for the people to remain strong and united and for statehood to be sustained, the Fon at the head of the dynasty had to adopt some political mechanisms and strategies to contain pressure from his opponents or detractors as well as maintain the various groups under his control. In fact, he is said to command the instrument of conflict management, resolution and mediation in his community. Through books, memoirs, thesis and interviews, we concluded that conflict is a characteristic of power politics and no system is free from it given the 'omnipresence' of ambitious detractors. Thus, the ability the Fon to hold Bafut together under his control makes the fondom a perfect example of unity in diversity and master of the politics of peaceful coexistence.
\end{abstract}

Keywords: Fonship, Power Politics, State Formation, Bafut, Cameroon.

\section{Introduction}

Traditional administration, power politics and authority in Africa revolve around the power structure and traditional set up established by the various communities. In Bafut, power and politics is focused on the personage of the leader (Fon) and the
Divine Fuhnwi NGWA

Protestant University of Central Africa

(PUCA), Yaounde, Cameroon

E-mail: divinefuhnwi@yahoo.com

Conflict Studies Quarterly

Issue 21, October 2017, pp. 50-75

DOI: $10.24193 / \mathrm{csq} .21 .3$

Published First Online: 10/03/2017 
throne. A number of events influenced the throne of authority and its occupants as the society evolved. Politics of coexistence between groups which accommodated themselves under circumstances since pre-colonial times portrayed Bafut as one of those centralized political entities in the Bamenda Grassfields of Cameroon that exhibit a hierarchical power structure externally viewed as cohesive and consensual. The perception of fonship or paramount rule (among people with different backgrounds and agendas) is viewed from a rebellious stand point, thus necessitating some strategies and methods to be used by the Fon to maintain his grip over such a diversified polity. However, elements that influenced power politics and authority around the Fon either acted as causes to strengthen his position on the throne, reinforced his authority or generated tension and conflict within the realm of traditional politics. Ironically, the same elements served as instruments that maintained peaceful coexistence amongst the people, thus suggesting that the reign of peace does not negate conflict. Actions taken by the Fon and his people constituted the power politics around the fonship. In fact, fonship in Bafut is not given but worked for and how the Fon manages his people (conflict resolution or management) in a bid to maintain peace depends on the strategies and methods adopted from inception.

\section{Background}

Bafut is a composite kingdom made up of eight semi-autonomous chiefdoms. It is situated some twenty kilometres North-West of Bamenda, capital of North-West Region of Cameroon. It covers an area of some 340 square kilometres with a population of nearly 98000 inhabitants. This population is made up of peoples from diverse backgrounds settled in three zones. At the centre are the people of mumalaa (heart of the country) who trace their dynastic origin to Ndobo or Tikari area, North-West of Fumban in West Region of Cameroon. To the South and North are the ntare (ridge area) and mbunti (lowland) people of Widikum origin from South-West Region of Cameroon. Bafut is a polity with a paramount chief (Fon) under whom are sub-chiefs that administer different ethnic groups of diverse peoples within the Fondom. The dominant group in whose hands supreme power resides is the Tikar and the sub-chiefdoms are mostly of widekum origin. The sub-chiefs in Bafut claim to have brought their people into Bafut from various places of origin. Thus, the paramount Fon's right to exert local authority or control over their people is not legitimate (Niba, 1999). Such claims have not only threatened the survival or existence of traditional authority in Bafut but have also incited ethnocentrism and other vices in the Fondom. The uncompromising stand of the Fon, his chiefs and people threatened to tear the Fondom apart. However, the power and authority of the Fon had its roots from the socio-political arrangements and relations that were established in the area from inception. 


\section{Social and Political Organisation}

Bafut society was patrilineal in its kinship relations. It means that descent and succession was claimed through the father. Any son was entitled to succeed provided the father indicated this in his will. The smallest unit of the kinship group was the nuclear family (nji inda, meaning, bottom of the house). This was synonymous with the smallest territorial unit of the fondom, namely, the compound (ndugu), which consisted of a man who was the compound head (mbong ndugu), his wife or wives, unmarried sons, daughters, servants and other dependents. The compound head could also be the head of an extended family or a patrilineage (ngwe'enda), which came next after the nuclear family. Coming after was the lineage (acheu), consisting of a number of extended families whose members claimed descent from a common ancestor. It was headed by the successor of the founder of the lineage (tacheu). A number of lineages constituted a village.

As mentioned earlier, the Bafut fondom was a heterogeneous polity. It fitted broadly into the class of African 'incorporative kingdom'. The characteristics of such a kingdom, according to Vansina (1962), were (a) that it had been enlarged by conquest, (b) that the conquest started from a nucleus and (c) that the impetus to the conquest was given by an immigrant group. Thus, at the head of the political structure in Bafut was the Fon. He was both the political and spiritual head and also exercised both executive and judicial authority over his subjects. His position was re-enforced by the near-sacred nature of his personality (Ritzenthaler \& Ritzenthaler, 1962). The Fon had multiple political, judicial, religious and social duties. He controlled external relations with other peoples, making wars and peace treaties. Internally, he made laws. All justice was in his name and he was the final court of appeal and had the power of life and death over his subjects. As chief priest of the fondom, he offered sacrifices to his ancestors and interceded with them for the welfare of the people and for peace to reign. In summary, the Fon was the visible manifestation of the Bafut body politic, but at the same time he was merely the tip of the political iceberg.

As in most African kingdoms, the Fon of Bafut was assisted by some royal relatives, namely maamfor (queen Mother), two brother assistants to the Fon, namely the ndimfor (elder brother) and muma (younger brother), who also served as advisers. There was another brother adviser. This was Tabufor (father of fons). He was usually any son of the late Fon who happened to have been born before his father was enthroned as Fon. By the circumstances of his birth, therefore, the Tabufor had no ambitions for the throne, hence his role as father to the new Fon. In this capacity, Tabufor had the obligation to support the Fon in all ventures that were geared towards maintaining peace in the fondom. However, none of the royal advisers acted as regent when the Fon died or was absent from the palace. The body which shared power with the Fon and acted in his absence was the council of elders or kwifor. Literally, kwifor means holder or supporter of the Fon. It was an institution common to all the Grassfield kingdoms and was called 
different names. Thus it was called nwerong in Nso, kwifoyn in Kom, nkwifon in Mankon and ngumba in Bali, all studied by Chilver and Kaberry $(1959,1961)$. The members who must have reached the bukum rank were hierarchically ordered.

The functions of kwifor were carried out through different agencies or lodges. One important duty of kwifor included the enforcement of rules regarding the authority of the Fon and the decisions he took. Kwifor worked hard towards maintaining peace in the fondom. It resolved conflicts within the context of a judiciary system that was set up in the central palace. The Bafut judicial system, as analysed by Chilver and Kaberry, was broadly similar to that of another 'Tikar' Kingdom, Nso (Chilver \& Kaberry 1963; Cullock, Littlewood, \& Dugast, 1954). The point of agreement is that justice was decentralised as much as possible and the Fon only dealt with serious cases. As far as possible, disputes were usually submitted for arbitration and settlement in family circles, from the extended family up to the lineage, depending on the nature of the case. Beyond the family, quarter and village heads dealt with some cases between families such as thefts, assaults and land matters. More serious cases, such as murder, arson, witchcraft, destruction of property and aggravated thefts were referred to the Fon who dealt with them in consultation with kwifor.

Depending on the gravity of the case, investigations were carried out by kwifor. In a land case, for instance, some bukum would be sent out to investigate. While the case was sub-judice, the area in question would be put under the kwifor ban. The insignia was a stick with a slit top in which a palm frond was inserted (ajube kwifor) and pinned on the disputed piece of land. On the appointed day, both parties to the dispute came to the palace. Evidence was taken separately from them by kwifor messengers (nto kwifor). This was relayed to the Fon who, on the advice of kwifor, arrived at a decision. On another day, the Fon would deliver judgement in the audience hall (nsang). Criminal cases were dealt with in the same way. Kwifor would carry out the investigations, the Fon delivered the judgement and the appropriate arm of kwifor would execute the sentence.

Sanctions followed the moral, ritual, and legal guidelines as analysed in the cases of some West African political systems by Brown (1951). In Bafut, the category of sanctions depended on the gravity of the case. In the case of witchcraft, there had to be exculpation by ordeal in the kwifor inner lodge (ndangoro). The suspect brought a fowl to which poison was administered. The death of the fowl signified guilt. This was similar to trial by ordeal as discussed by Ikime (1965) in the case of some Delta tribes in Nigeria. The guilty person was then either executed or exiled. In the case of murder, the murderer was publicly executed by being tied to stone monolith in the plaza and clubbed to death by a masked kwifor executioner (mubu'u). Assault was punished by demand of compensation. The punishment for theft was public disgrace and mockery. Cases of treason, that is, those against the person of the Fon and abominations such as adultery with a Fon's wife warranted instant death in the hands of kwifor. In fact, 
modern states today might consider these methods as a slight or an anathema to human rights ethics. In reality, the 'dreaded' nature of the sanctions acted as a deterrent to criminality in the society. The fear to be sanctioned by kwifor, reduced crime waves which permitted the Bafut people to live in a peaceful atmosphere.

On territorial organisation, Bafut had two types of settlements. The first one, there were the semi-autonomous villages each with its own chief (atangchuo - war planner). The villages were linked to the centre under various conditions governing their relationship. According to Hook's list (1934), as mentioned above, seventeen villages fell in this category. They were: Bawum, Mambu, Mankaa, Mankwi, Banji, Akofunguba (south in the ntare area); Beno, Buwi, Manta, Tingo, Mbekong, Butang, Bugiri, Aba and Bukabunano (Obang). Most of them were located North in the upper Mentchum valley. There was Bukari and Buwe, being among the oldest villages in Bafut located to the northeast of the capital.

The second type of settlement constituted those villages clustered around the palace and ruled directly by the Fon. These were: Mbebali, Mbebeli, Manji, Njibujang, Bujong, Njinteh, Niko, Mankaha, and Nchum (Hook, 1934). The inhabitants here consisted mostly of the Tikari immigrants, who were closely allied to the Fon. These villages had no chiefs with any hereditary title as such but an appointed head (tanukuru - father of the quarter) existed. He was appointed by the Fon among the bukum of the village, that was, any one of them whom he deemed competent. In some cases, a prince was appointed. That was one way the Fon involved his relations in the administration. The tanukuru, along with the other elders of the village constituted a governing council (butabenukuru), which met often to deliberate on matters of immediate concern to their village. The matters might be the implementation of the Fon's directives, collecting and transmitting their own tribute to palace and arranging for community projects. They were also charged with the duty of resolving conflicts and restoring peace in their villages.

It was also the prerogative of the Fon to create new villages, by appointing heads to new settlements. It was by doing so that he had more villages under his direct control. However this does not imply that the exercise of power on Bafut territory was smooth through; there were areas of conflict within the political structure (Mair, 1977; Rowe, 1975).

We stated above that, the Bafut dynasty claimed origin from Tikar, from which the legends bring the ancestors of the kings just as those of Kom and Nso (Hawkesworth, 1926; Hook, 1934). As a composite fondom, the different component chiefdoms had their own traditions which were at variance with the central fondom. A typical example was the chiefdom of Bawum whose traditions place their roots of origin from Ala'ante near the present Bamenda Station. Driven by natural disaster, their chief, Ntoh, led them towards Bafut and settled at Mbebeli as guest of Nibachi, the chief. Then came a man from Tikari named Firlu who attracted the people to him by his generosity. Finally 
Ntoh and Nibachi surrendered the kingship to him and he founded the present Bafut dynasty (Hawkesworth, 1926).

The Bafut palace and, by implication, the central government, remained in Mbebeli for some time. Later, one of Firlu's successors moved it from the rocky and hilly location of Mbebeli to its present location at Mumalaa (Ewusi, 1978). Traditions attributed the initiative of this transfer to one of the Fon's wives who went fishing with other women in the Nkinsari stream at Mumala. On exploring the surroundings, she discovered some level land. Thinking that it would make a suitable site for a palace, she took the idea to the authorities. They readily endorsed the idea and effected the move. But, soon afterwards, something went wrong. Fearing that the woman might start feeling proud and hence make unacceptable demands for preferential treatment, palace diviners recommended that she should be eliminated. She was thus killed at a nearby square called Nsanimunwi. It is held that a pit trap was prepared and camouflaged. Over it was placed a ceremonial stool. Lured to the place under the pretext that she was being honoured, the woman sat on the stool and fell into the pit which became her grave. Tradition nicknamed this unfortunate woman Ndiela'ambwe, meaning someone who did something good but was rewarded with evil (The Bafut Public Confessions, 1996). The Ndiela'ambwe issue is an episode deeply embedded in the collective psyche of the Bafut people.

The expansion of the Bafut fondom from its new base at Bujong in Mumala'a could be traced to both internal and external factors. The key external factor was the impact of the Bali-Chamber incursion into the Bamenda area at the beginning of the nineteenth century (Jeffreys, 1962; Chiver \& Kaberry, 1970). The Chamber incursion apparently affected the balance of power in the area. It brought them into conflict with the bigger chiefdoms and induced the smaller ones to seek refuge under the bigger chiefdoms. Bafut after a clash with the Chamba, became a rallying point for refugees from the south and southwest of the Ngemba area (Tweed, 1926). Some of them eventually returned to their places of origin while others remained. Among them were the chiefdoms of Mambu and Mankanikong, both of whom claimed to have come from the same area, Mberewi (Chilver \& Kaberry, 1970). These chiefdoms became tributaries of Bafut through voluntary submission. How voluntary was the submission cannot be ascertained for conflicts and misunderstanding periodically flared between these two chiefdoms and the central authorities.

Another external factor was land hunger which led the Bafut to expand northwards into the Mentchum valley around the middle of the nineteenth century. It was also dictated by the desire for tribute. In a series of raids, the Bafut conquered peoples such as the Otang, Buwi, and Bugri. Others, such as Mbakong, Manta, and Butang, voluntarily submitted (Warnier, 1985). Such expansion was what made Bafut to be termed a conquest state. Another area which Bafut brought under its control was Njimuya, across the Mezam River, with its rich savannah farming and hunting grounds. Apart from subduing the 
inhabitants and making them pay tribute, some Bafut started migrating and settling there. The Fon of Bafut personally offered land and raffia bushes to his well-wishers and strangers in this area.

The migration of Bafut people piecemeal into uninhabited areas in search of fertile land was a key internal factor of fonship and power politics. The necessity to expand was due to a population increase from the middle of the nineteenth century resulting from conquest. According to Warnier, quoting from Pavel, the German officer who led expeditions into the Northwest, Bafut, in 1890 had around 25,000 inhabitants from diverse origins (1985). This population needed land for sustenance. Bafut people thus started moving and settling in the Mentchum valley and Njimuya. This trend continued as migrants moved later on into Agyati, Ntabuwe, Akosia, Nforya and very recently Nsoh. As they moved into these new lands the Bafut elements preferred to continue to maintain their allegiance to the Fon of Bafut rather than to the chiefs of the area. That is what gave Bafut the characteristics of an incorporative kingdom, following Vansina's typology (1962). Such an arrangement showed that initially, the act of incorporation was peaceful but it would sooner or later breed conflicts, as local rulers found their power being whittled down by the encroaching influence of the central authority. One thing to ask at this level is how the Bafut indigenous government was sustained. The maintenance of government everywhere requires some strategies and mechanism. These came from the Bafut people themselves. The Fon was the custodian over the land he had overall control of the economy but it was the people who exploited it to maintain the palace. It was incumbent on them to do so without demanding payment in return. Whatever the Fon gave in return was only token appreciation. Though some people considered it a privilege and honour to respect the authority of the palace, some usually resisted. Sanctions followed any recalcitrant behaviour with the intention of resolving the issue at stake. However, this sometimes result to conflict and power tussle. The people in search of an instrument of governance, established a frame of traditional authority to assist leaders administer the people peacefully.

\section{The Frame of Traditional Authority}

Traditional authority in Bafut operated within a given frame and context. A local network existed in the community that was not written down in any form of constitutional law. It appeared as a moral code of customs and traditions which the people had to implement in their daily life. The respect of customs by the people was the key instrument of conflict resolution and peace building in the fondom. The non-respect was tantamount to conflict given that the leader (Fon) was intolerant to acts that violated the traditions of the land. In fact, it was at the level of executing tradition that the authority of the leader was strengthened, weakened, or generated power tussle within the political arena and community as a whole. 
Traditional authority and its practice in Bafut began at the level of the family - the basic unit of society. Bafut people adopted a polygamous institution of marriage. Constant quarrels and hand fisting were rampant in these families because each member struggled to protect his or her interest or grasp as much of the scarce economic resources available for the family. Such struggles impacted on the authority of the family head that had to use authoritarian methods to ensure peace amongst his family members. The royal family at the central palace was often a large one with many wives and children. In the reign of Achirimbi II, he had about 50 wives and over 100 children (Ritzenthaler \& Ritzenthaler, 1962). The personal interest of its members generated tension within the family. Since the family and its head were directly linked to power, problems within it had an impact on traditional authority in Bafut. The Fon needed to be authoritative to manage his large family. Such attitude became conspicuous in his governance and administration of the entire fondom.

The second entity identified with authority within Bafut was the lineage (acheu). The large polygamous families in Bafut, led to the formation of very large and extended kinship groups called acheu. Survival of individual interest here depended on how the concern was capable of imposing his authority in the system or lineage. The struggle for dominance and authority in the lineage developed zeal among members to extend their influence to other political issues and institutions in the society. Hence, the authority of lineage heads became elastic and influenced the society in different ways and at different levels, and for different motives.

The descendants of the Bafut royal family are spotted all over Bafut. They constitute a lineage called acheu firlu. In recent times Abumbi II renamed the lineage acheumefor. In the quarters and villages of Bafut, these descendants formed houses called ndabelubentoh. Here, they did not only defend their personal interest and that of the royal lineage, they acted as spies on the sub-chiefs, quarter heads and other traditional authorities in the villages. All acts committed by the villagers, chiefs and quarter heads, which defied tradition or challenged the authority of the Fon and his lineage in Bafut were reported to the palace by the belubentoh (Ngwa, 1996). Through the belu, the instrument of justice and conflict management designed at the central palace by the Fon and kwifor was transmitted to the quarters and villages. Hence, chiefs who fomented conflict in the fondom or arrogated something meant for the palace had their authority questioned by the belubentoh.

One aspect of authority in Bafut is that the traditional leaders (fon and chiefs) were first of all considered as lineage heads before being leaders in general. Hence, we may talk of acheufirlu or acheumefor in the central chiefdom (mumalaa), acheuntoh in Bawum, acheuwanki in Mambu, acheutanga in Mankanikong and many others. Within the villages (chiefdoms), other powerful lineages existed and their influence on political issues could not be minimised. They were conferred some specific political duties to handle in the 
villages. No other lineage was permitted to perform such duties. For instance, in Bawum, three powerful leneages emerged, namely acheu Mufersi, Ntumgia and Ntoh. Ntoh had to rule in consultation with acheu Ntumgia whose lineage head was the leader of kwifor Bawum. In Mambu, acheu Munsoh, Tamfuh and Wanki emerged. In Mankahnikong, we had acheu Wanzie and Atanga. The political influence of these lineages went beyond their chiefdoms given that some were charged with the duty of appeasing the gods of the land for the well-being of the entire fondom. Thus, it could be said that all the chiefdoms of Bafut had powerful lineages that acted as political bulwarks. An interwoven network of authority was created amongst them, thus making power tussle inevitable in the system. The Fon and the central palace acted as the pivot or centre of action, ensuring that peace reigned at all times and in all circumstances.

The next authority was that of Quarter Heads (betabenekuru). Villages in Bafut were divided into quarters. A group of compounds or lineages made up a quarter. The administrative structure of the quarter was carved out into small groupings of about ten lineages each, called ayenda. Lineage heads from the ayendas worked their way up to constitute a council of quarter heads called betabenekuru. Their positions in the council were not hereditary. Membership into the council was through the gift of food and drinks to the palace authorities and older members of the council. However, the Fon had the prerogative to appoint a quarter head of his choice. The authority of the quarter head was enforced by a traditional rite performed on him by the Fon and central palace authorities (Chilver \& Kaberry, 1963). In the course of this rite, the concern pledged total loyalty and allegiance to the Fon and palace institutions. He was instructed to rule Bafut people in his quarter in the name of takumbeng and kwifor. They were asked to use the authority conferred on them to maintain peace in their quarters. In fact, the pledge of loyalty an allegiance was exploited by the Fon to curb the power or excesses of political rivals. By so doing, he ensured peace and tranquillity within the political arena.

Lineage heads from common origin and princes were nominated as betabenekuru. Amongst the Betah, two were further nominated to constitute the senior quarter head and the assistant. One of them must be a prince and the other a commoner (Hook, 1934). For the fact that the princes of the royal family were brought up in the spirit of absolute authority and dominance, they imposed their will with impunity on the rest of the council members and people in the quarters. Princes were dreaded and feared in the quarters. Sometimes, they challenged the authority of village heads (chiefs) and threatened to dethrone them. Besides, all tanekurus (quarter heads) were compelled to be members of either ndakwifor or ndatakumbeng. In this way, the many quarter heads in the villages of Bafut were directly linked to the political system at the central palace. The prerogative accorded the Fon to appoint quarter heads, made his palace the hob of political action and issues in the fondom. In other words, the Fon's palace became the reference point for all problems and resolutions. 
Authority was also vested in village heads called batangcho. The English equivalence of an atangcho is a sub-chief and the word is used here to distinguish the authority of the atangcho from that of the Fon who is the paramount Chief of Bafut. Unlike the position of the tanikuru, that of the atangcho is hereditary. The tanikuru is like a helper to the Fon or atangcho in the quarters. Also, batangcho are believed to be leaders of ethnic groups that migrated into Bafut and who have succeeded in maintaining their political identity and different languages in the area. They have dynastic claims which make their position hereditary. These leaders were also allowed to use their customs and traditions of origin to administer their groups or villages in Bafut. They were also permitted to use their languages of origin and to manage the problems of their people following their customs and traditions of origin.

However, the political institutions of the tikar group seemed to have been a source of inspiration and admiration to many of these leaders. They decided to copy and used to administer their people. Such attitude, rather than create a harmonious and peaceful atmosphere in the fondom, prepared grounds for future political tussle. The institutions were used by the Sub-chiefs to challenge the authority of the Fon, thus creating conflict within the political structure. The authority of the atangchos was further enhanced by hereditary royal titles accorded them over their villages. Their royal families were clearly distinct from that of the paramount chief (Fon). The influence of its members was limited strictly within their villages. In no occasion was the status of a prince from such royalty equated to that of a prince from the central palace. The following sub-chiefs benefitted from this arrangement: Ntoh Bawum, Wanki of Mambu, Atanga Muwah of Mankahnikong, Talah of Mankwi and Banji, Nano of Obang. Others emerged to join the folk with time (Aletum, 1974).

In spite of this, the authority of these leaders gradually withered to the advantage of the Fon and his palace. How did it happen? Bawum and Mambu are very close neighbours in upper Bafut (ntare). Both leaders developed an aggressive and expansionist tendency which finally indulged both villages in a border conflict in the 1950s. Due to the uncompromising attitude of the two leaders, the Fon, Achirimbi II, was called in to resolve the problem. The verdict was in favour of Mambu. This permitted the Fon to win the loyalty and allegiance of the Mambu leader who saw him as a shield against his enemies. On the part of Bawum, she was unable to protect her boundaries with kwen and Mankon at Mubang, Swei and Nsoh. The Fon was obliged to organise his militia to push out the invaders. To protect the land, people and princes from mumalaa were encouraged to settle at Nsoh, Swei and Mubang. These settlers eventually paid allegiance to the Fon of Bafut and not to Ntoh Bawum. He had lost grip and authority over these areas thus reducing his influence to a very small and accidental piece of land around his palace at Bawum. In lower Bafut (mbunti area), inter-village wars were fomented by Chief Nano of Obang and Talah Banji in the 1950s and 1960s (Ngwa, 2010). Talah Banji occupied Mankwi land on the borders between the two villages. The Mankwi people reported 
the matter to Fon Achirimbi who intervened to solve it. Achirimbi did not only succeed in winning the loyalty of the Mankwi leader who saw him as a liberator and protector, but he reduced the authority of the Banji leader in the area. Achirimbi sent strangers, Bafut people and princes to settle in Banji. The people watered down the authority of Talah Banji as they paid their taxes directly to the Fon without passing through him. In a petition to the District Officer for Bamenda the Village Head of Banji wrote:

The following people namely Wanki, Ndifobanyong, Lasarous Nche of Mankon, Muchi, Mfocham, Mundaban, Tangoni, Ngonga, Akimawa, Nyambu, some of whom are the Bafut people and strangers reside in my village Banji, and paying their taxes direct to the Fon of Bafut as being corrupted by One Nyambu of Bafut who is used as a tool by the Fon of Bafut to torment me and my people all the times. I had previously appealed to the District Officer that cairns be inserted in the boundary between me and the Bafut village in order to avoid this year in, year out discrimination... (Village Head of Banji, personal communication, August 3, 1954) .

These people went further to occupy raffia palm bushes from where they taped palm wine and sent to the palace without consulting Talah Banji. The Fon, on his part, carved out good number of palm bushes and kolanut trees for himself in Banji. He needed no permission from Talah to do so and Talah had no voice to question the action or authority of the Fon. In the 1960s, Nano, the village head of Obang invaded Mbakong and Ndong. The Fon, Abumbi II was called in to provide a solution. In fact, each time the Fon of Bafut was called in to intervene or mediate in a village issue, it was an opportunity for him to project his image and authority at the detriment of the village heads. That is how they lost their authority, thus making the Fon supreme in the entire fondom. One thing is notice here and it is the fact that the role of mediator in conflict resolution worked in favour of the Fon who exploited every opportunity offered by his political rivals. Though the Fon portrayed a 'predator' character in conflict resolution, it was a useful strategy for him to restore peace in the fondom.

As mentioned earlier, the titled sub-chiefs with dynastic claims developed centralised systems of government in their palaces similar to what was obtained at the Fon's palace. For instance, the chiefs retained their kwifors and other political institutions which are being used up till date. This made the chiefs to see themselves as equals to the Fon and not subordinates. They also considered the villages under their control as independent polities free from any subordination under a so-called superior leader. When the Fon and central palace authorities discovered that the sub-chiefs were effectively using the traditional institution of kwifor against his authority, he embarked on their seizure. In fact the kwifors of Bawum and Mambu were seized thus projecting the authority of the Fon in these chiefdoms. Many other royal Paraphernalia belonging to the chiefs were seized. For instance Chief Ntoh of Bawum wrote to the prime Minister of West 
Cameroon complaining about the treatment meted on him by the Fon and his children in Bafut. Ntoh Bawum wrote:

The Fon and his children were against me. Ngwa Chunga, one of his sons on 8/2/68...got me beaten and seized my traditional walking stick, my traditional bangle and umbrella from me and took it to the father. Since when I was installed in my father's throne in 1962, I have never been at rest in the hands of the Fon of Bafut. He caused the police to burn down my market... The Prime Minister was aware of the fact that this dispute is because of me (Ntoh), and the Fon of Bafut were not in terms. I Chief Ntoh am the same as the Chief of Kwen, Bambui, Bambili etc. under Bafut. And as to the chief of Ngembu and many others in Meta under his highness Fomunyen, they have their different boundaries. You cannot see fomunyen worry any of these chiefs why is it that I cry every day from the Fon of Bafut. I will be grateful if the Prime Minister can mandate a board of inquiry in Bafut for this issue in order that I should achieve my right in Bafut or else greater trouble may come. Nearly all my things and properties are being seized by the Fon of Bafut (Ntoh Bawum, personal communication, 1961).

Actually, the tendency of copying the traditional institutions of the tikars by the chiefs made them to be caught in their own trap. When the British colonial masters came to Bafut, the Fon used the 'copy right legacy' to assert his superiority over the chiefs in the area. The British validated the argument and assisted the Fon to suppress all oppositions against him. Unfortunately, the seizure of things (njoo) and kwifors of other chiefs was not to the point of rendering their influence or interest ineffective. From time to time, they presented traits of competition between the central palace and the sub-chiefs. To survive from such traits and for peace to reign, a number of strategies had to be put in place by the central palace.

\section{Strategies Used to Sustain Fonship in Bafut}

The first strategy is the position of fon itself. The throne of the Fon is sacred and surrounded by an aura of power and myth. All power and authority is focused on the personage of the Fon who is worshiped as a demigod. All other things in the polity are done in the Fon's name. His word is law and must be respected by all and sundry. As the society evolved from one period to the other, the Fon's authority and position over the throne was strengthened and reinforced by new strategies adopted to deal with the issues at stake.

Generosity and redistribution was used by the Fons to reorder an internal hierarchy in the area. Generosity in our context is the demonstration of selflessness and sympathy by a leader towards his people. Redistribution, on the one hand, is the ability of a leader to share what comes to him or belongs to him with his people and close collaborators. This is typical of African tradition and any occupant of a coveted political position of 
leadership in society is naturally compelled to exercise it. History holds that the ruling dynasty in Bafut was created by an immigrant tikar leader, Aghaanjoo, who migrated with his followers from ndobo in North Cameroon to Mbebili in Bafut. On arrival, he met Nebachi, the indigenous leader who gave him accommodation. Nebachi had earlier hosted Ntoh Bawum who migrated with his people from laante around Bamenda up station into Mbebili. With the arrival of Aghaanjoo, three leaders and three different ethnic groups were living together in the Mbebili vicinity. In the character of the tikar leader he was generous and feed the people through effective redistribution. Nabachi, according to the people, was a selfish and hand fisted leader who failed to ensure redistribution or feed his people. A coup was hatched by the nobles of Nebachi for the the tikar leader to take over the throne and leadership of the area from Nebachi. The plot was materialised on the day of Nebachi's annual dance. The nobles of Nebachi encouraged the tikar leader to deliberately step on the toes of Nebachi. When he enquired to know the meaning of such act, he was told by the nobles that it was a sign of his deposition from the throne of leadership. Frustrated and wounded by this betrayal, Nebachi decided to commit suicide. The tikar leader took over the throne which his generations had occupied up till date.

It can therefore be said that generosity worked in favour of the tikar leader. He surmounted his subordinate position under Nebachi by feeding the people through effective redistribution. The gesture of the foreign leader was appreciated within a social context by the people but politically it was dangerous. Aghaanjoo used it as a ploy to seize power and assert tikar hegemony over old chiefs like Nebachi and Ntoh Bawm (Engard, 1989). Politically, therefore, the Fon's largess never went for nothing. Thenceforth, their extension to particular groups in the area was used as a bate to lure 'preys' for subjugation and domination. On the one hand, selfish attitudes and tendencies henceforth became a cause of political wrangles between the Fon, his subaltern chiefs and people as a whole. In the reign of Achirimbi II, for instance, he was accused by his sub-chiefs for being crafty, hand fisted and selfish. This constituted one of the strong causes that provoked the chiefs to confiscate the Fon's tributes in the chiefdoms (Ngwa, 2010). The outcome was the struggle for secession that rocked the last two decades of Achirimbi's reign. Again, in 1968, a succession conflict occurred in the royal palace amongst the princes of the royal family. One of the causes of the conflict was the problem of generosity and redistribution. Some sub-chiefs opted for a change of the successor willed by Achirimbi because they claimed that he was going to continue or enhance the selfish attitude of the late father. The members of the royal family were also against the choice because according to them, the mother of the new Fon was crafty and selfish. As a would-be Queen mother, she would not be able to ensure generosity and redistribution to the entire royal family and the Bafut community as a whole (Ngwa, 1999). Hence generosity transforms situations of leaders in the political arena. The ability of the Fon to extend his largesse to the people was an impeccable instrument of conflict resolution. Through 
this, the Fon impacted the hearts of his people who in their happy mood gave unflinching loyalty and support to their leader. A stable government under the firm control of the Fon was synonymous to the reign of peace and coexistence in the fondom.

A strategy of surveillance, to eliminate threat in advance was also put in place. After the death of Nebachi a thorough mechanism of keeping watch to eliminate political threat at all times was instituted. The stepping on the toes of Nabachi by a foreigner was a violation of his sacred personage in a public performance that was intended to reconstitute or galvanise his authority as the overall leader or chief in the area. But that was not the case as Nebachi turned out to be highly exposed to danger and detractors. Giving the sacred personage of the Fon, henceforth, an elaborate protocol and security procedure was put in place to ensure that no one ever touched the Fon in public. However, a few wives and retainers were permitted to get close to him and discuss with cupped hands in their mouth (Engard, 1988). From here emerged the bureaucratic and bottleneck procedures that were instituted in the Bafut palace. For somebody to see the Fon of Bafut (for anything) was like an elephant going through the eye of a needle. A number of procedures accompanied by payments had to be followed before seeing the Fon. Also, the stepping on the toes was now interpreted in various ways. For instance, if someone crossed his legs in the presence of the Fon, that was interpreted as claiming more rights or equal status with the Fon. The people learned to maintain peace by respecting these bureaucratic procedures and the dues that accompany them.

As society evolved the act of stepping on the toes of the Fon took a different dimension. It did not necessarily require the physical stepping on his foot in public. Any opposition to the authority of the Fon from whosoever and in whatever form, was interpreted as stepping on the toes of the Fon, thus an attempt to seize power. Within this background, Fons like Abumbi I and Achirimbi II were intolerable to challenges that tempered with their power and authority. They opted to crush all manifestations of such acts before the 'stepping process' ever mature to fruition. Here, a plethora of spies and acolytes of the royal palace were deployed in all the quarters and villages of Bafut to secretly monitor the daily activities of the sub-chiefs and report to the palace for prompt intervention. In fact a network was set up to keep vigil over the sub-chiefdoms and their leaders so that nothing ugly ever surfaced from their bosom. In the reign of Abumbi I, chiefs who used their kwifors to challenge the authority of the palace and its own kwifor, were reported to the palace for prompt seizure of the instruments. Spies from the central palace were deployed to waylay the kwifor on the least outing occasion and seize the instruments. In the reign of Achirimbi, chiefs who arrogated tributes from their people destined for the palace were reported by palace spies and Achirimbi II immediately engaged court action against them (personal communication, 1954). Abumbi II, on his part, sent his palace authorities and kwifor to depose chief Nanoh of Obang for inviting the kwifor of Kom to attend the death celebration of his late father without the permission of the central palace. It was through the forceful intervention of state administrators that Nanoh was 
reinstated. In fact nobody stepped on the toes of the Fon of Bafut and went free. Many of such attempts were nipped by a network of surveillance before they matured. By so doing, the Bafut fondom became an epitome of peace.

The rule of the nobility (bukum) was instituted as an instrument of power politics in Bafut. After the episode at Mbebili, a new interpretation was given to the action of the nobles who plotted against their own chief Nebachi. The act was not a simple palace coup per se but a revolution which necessitated a radical reorganisation of the Bafut political set up. In this new dispensation, the influence of the chiefs of the ethnic groups in Bafut gradually disappeared from the scene of political importance. Nobles or councillors replaced the chiefs within the central palace politics. They became more powerful as the Fon used them to protect his own authority (as his kingmakers) and to clip the authority of his main rivals or challengers who were the chiefs (Nebachi and Ntoh Bawum) from whom the throne was seized at Mbebili. These nobles called bukum formed a powerful clique around the throne of the Fon and ensured that all moves taken by the sub-chiefs to destabilise the power and authority of the Fon were foiled.

However, in the new set up, Nebachi was recognised as primus inters Peres among the three main leaders of the area due to his historical primacy. Hence Nabachi and his family were represented in the new set up by one of his wives called Ndeulaa. According to history, Ndeulaa was the founder of the new palace site at Bujong in mumalaa (the depression). By virtue of this, Ndieula had her rank increased in the new government at Bujong. She was given immense honours and privileges as founder of the new palace site. This directly or indirectly projected the image and position of the indigenous leader, Nebachi, (her late husband), and his family line in the new palace set up. This was synonymous to saying that although Nebachi died, his spirit and power continued to reign. His political influence was still felt through Ndieulaa's coveted rank in the new palace government at Bujong. Here Ndieulaa developed an insatiable quest for power and honours as well as material benefits accruing from the system. She was seen as a threat to the Bujong government. Old memories of the late husband, Nebachi came back. Palace authorities quickly concluded that Ndieulaa manifested greedy and crafty tendencies in like manner as the late husband.

Besides, the persistent complains and requests of Ndieulaa represented a new Mbebili insurgence to get back the husband's coveted throne. Ndieulaa's powers were getting into excesses and she more or less became a potential threat to the system. It was possible for her to revert power to Nebachi's lineage if something was not done to check her overriding influence or quest for more powers. With this impending political threat, the palace decided to eliminate Ndieula. She was made to sit on a chair at a public site near the palace called Nsanimunwi. She was told that they wanted to honour her and attribute the honours and things she complained about. A stool was prepared over a dogged grave on which she was lured to sit for the traditional rites to be performed on 
her. Once on the stool she sunk into the grave and was buried alive (Aletum, 1974). This act was the last successful plot against the indigenous leadership which completely effaced the dregs of indigenous political influence within the Bafut administrative system.

The death of Ndieulaa was an event that had continued to influence Bafut politics up till date. Scholars over the years have analysed the event from different angles. According to Engard, the unsatisfied demands of Ndieulaa did not only amount to an indictment of the Fon's generosity but was also a challenge to his capacity or ability as the sole redistributive focus in the kingdom. The complaint portrayed the Fon as a selfish and hand fisted leader. It was not different from the accusation earlier levied on Nebachi. Paradoxically, the nobles did not see the complaint of Ndieulaa genuine enough to dethrone a crafty Fon. Instead, they saw her complaint as an impending threat to the throne. Under the guise of saving the throne, the nobles took action against Ndieulaa and killed her. Engard further remarked that Ndieulaa replacing Nabachi in the political structure and clamouring for things (njoo) and power was in effect evoking the kingship which was seized or denied him. Ndielaa died in the context of an enthronement ritual designed as though to crown her fon (1988).

However the issue here is that while the council of nobles did not tolerate Neba Chi's lack of generosity and redistributive spirit, when it came to Ndieulaa's questioning of the Fon's generosity, they became intolerable. Many Bafut people in recent times feel that justice was denied Nebachi and Ndieulaa more than any other political actor within the Bafut fonship (nufor) and political system. The saying that do onto others what you think they can do to you, did not hold within Bafut politics. Interest and selfish aims controlled political minds and the tendency was for the central palace to inflict on others what they will not want such to reprimand them for. In fact sympathisers of Nebachi and Ndieulaa hold that the accusation levied against the two, the Fon at one point was guilty of the same crime and deserved similar treatment or sanction. But the fact is that what took place under Nebachi was different from what occurred at Bujong. At Mbebili, the people plotted against a leader who did not show any iota of generosity. But in the case of Ndieulaa, she was honoured and given privileges and things (njoo). She requested for more indicating elements of greed in her character. The demand for more things was synonymous to seeking the throne or the position of the Fon and the things that went with such position.

The shameful stool on which Ndielaa sat to be crowned Fon and died brought back memories of the crown of thorns which the Jews falsely placed on Jesus' head as their self- proclaimed king and crucified. The clergy in Bafut had never accepted that Ndieulaa committed any crime to merit such death from the palace. That's why the church in the 1990s called for a public confession from the Bafut people to appease the spirit of the innocent woman (The Bafut Confession, 1996). Based on the argument of the clergy many Bafut people concluded that the methods used by the Fon to maintain himself on 
the throne or enhance peace in the society were markiavellic. But many political leaders can testify that in politics, such methods stand tall as useful instruments to enforce and safeguard the unity of a state. The authority of the leaders is also rescued in bubbling circumstances. Where they succeed, peace is restored and coexistence is maintained.

The mechanism of state formation and consolidation of power was set in motion to maintain peace and enforce the authority of the Fon. Bafut is one of the most heterogeneous polities in the North-West Region of Cameroon. How the people of such a diverse structure are held together under one paramount leadership is like myth to some people. The manner in which the polity was formed and the way power is being consolidated over it plays a pivotal role in holding the people together up till date. The Bafut ruling dynasty emerged at the new site of the palace founded by Ndieulaa in Bujong. The power and authority of the heads of this dynasty also grew along the lines of structural development and expansion in the area. Power was said to have been consolidated at the nucleus of the political structure following the elimination of opponents like Nebachi and Ndieulaa. From there, attention was tilted towards expansion. Small chiefdoms that were initially independent before the arrival of the tikars, were gradually incorporated by force or by guile under the authority and leadership of the tikar dynasty at Bujong. All new comers or strangers who migrated into the area were welcomed and accepted by the royal family. It was believed that the supply of agricultural labour and potters by the new comers will boost trade in palm oil and foodstuff production. All refugees, slaves and war captives were incorporated and their status transformed into free citizens with equal rights to a born Bafut (jweejwee befeu). Services to be rendered to the Fon and the entire royal household were to come from such people.

Also, the assimilation of strangers was imperative given that they were to be used to neutralise internal opposition, dissensions and detractors of the royal family. This arrangement, according to Warnier (1985), made Bafut to be open inside and closed outside. Strangers were admitted into the Bafut political system upon their declaration of unflinching loyalty and allegiance to the royal palace at Bujong. In return for the services, they offered to the palace, they were awarded titles and some rose to top positions of nkum within the nobility. The award of titles was accompanied by privileges, power and authority conferred on the individual by the Fon. For instance, a stranger who rose to the rank of a nkum was given a plot to settle in any village or quarter of his choice; he was given raffia and palm bushes to enhance his economic status. Some were given Bafut girls and princesses to marry, thus completing their assimilation process. The strangers had special mission to fulfil on behalf of the Fon and the central palace in the villages and quarters where they settled. They constituted cliques of palace acolytes who were determined to ensure that the authority of the Fon was respected in their areas of residence. The palace also used them to undercut the authority of leaders (chiefs) with claims to ancestral dynasties and ethnic origins in Bafut. In such circumstances, the Fon 
appointed palace acolytes to positions of sub-chiefs and quarter heads empowered with functions and privileges similar to those of the Village chief. Through this, the central palace and the Fon succeeded in using strangers (new comers) to consolidate their grip over the peoples in the area (Engard, 1989).

From the central nucleus at Bujong in mumalaa, the tikars undertook an aggressive expansion to the periphery driven by political ambitions and economic motives. They often began by cultivating far off farms at the periphery. This was followed by the construction of farm houses, locally called bush house, which was used for agricultural purposes only. With time, these houses were transformed to permanent settlements or residence leading to the emergence of a new layout or quarter. Under these circumstances, people in Bafut intermingled and lived permanently together in a new quarter. The people will eventually set up a government for themselves. But such a structure in an emerging community required recognition and representation as a polity in its own right. At this point, the central palace authorities at Bujong came in. The princes of the royal family led the crusade to ensure that royal authority was implanted and respected in these emerging polities. The princes constructed a small thatched hurt called ndereh-takumbeng at the ceremonial plaza of the quarter. This was the symbol indicating the presence of royal authority in the area. At the staircase of the ndereh a talking drum- kwin was placed. It was to be used to convey announcements and massages from the main one at the central palace to the people in the quarter. The ndereh-takumbeng was constructed in all quarters, new layouts and villages of Bafut as a symbol of royal authority. Every year, in the month of March, the quarters and villages organised repair works on the ndereh which in spite of its fragile nature, must never be allowed to collapse. Work on the ndereh-takumbeng was accompanied by traditional rites and ceremonies which compelled the people to pay tributes of palm oil and wine to the central palace (Ngwa, 2010). By this means therefore, the powers of the Fon and his palace were consolidated in all the nooks and crannies of the fondom.

In fact, the role of the princes in extending the authority of their father in the area was pivotal. Upon graduation from the palace, the princes opted to settle permanently in quarters, villages and sub-chiefdoms found at the periphery. This permitted them to exert royal influence and authority. They went further to challenge the authority of the sub-chiefs, thus reducing them to mere puppets in front of their people. In this way, the authority of high profiled leaders, like Ntoh Bawum, began to wither giving way to the primacy of princes and their takumbeng regulatory society. Engard (1989) remarked that Ntoh Bawum who was the third in command in the area dropped out of political influence. This was confirmed by the petition Ntoh wrote to West Cameroon government in 1963, about the attitude of the princes towards him. From the petition it was clear that the Fon of Bafut used his male children to dominate the political scene in Bafut thus ensuring that his power and authority prevailed over all dominions. The 
role of the princes in maintaining peace in Bafut cannot be over emphasized but what is clear is that there was a systematic method of assimilation that was put in place to simultaneously enhance royal power and authority in the fondom. The existence of peace in Bafut according to princes depended solely on the authority of the Fon and the central palace.

The kwifor regulatory society at the central palace was not left behind. The kwifor represented the estate of the commoners in Bafut. Commoners here stood for the entire Bafut population that was not related to the royal family. The kwifor house follows a stratified bureaucratic hierarchy where members begin as servants to the Fon and the system and then rise to the noble position of nkum and kingmakers. As nobles and kingmakers, kwifor members felt that they were closer to power than the leaders of the peoples in Bafut. The political arrangement at Bujong showed that the Fon shared power with kwifor and not with any other chief or leader. The same arrangement came out with a tradition which made the Fon a child of kwifor (mookwifor). By this arrangement, kwifor had the obligation to protect his child- the Fon from all dangers, opponents and detractors. Thus, there was an umbilical cord of political attachment and commitment to one another between the Fon and kwifor. Kwifor ensured that checks and balances were made to eliminate excesses in the powers of the Fon as he went about his royal duties. Yet kwifor was alert making sure that security was tightened round the throne to guard against any iota of threat that dared to depose the Fon. Instances are quoted in Bafut history where kwifor mythically or physically silenced contestants and opponents of the throne. In fact no chief came round the throne or passed on the corridors of power when kwifor was concerned. In this way, the nobles and kingmakers of ndakwifor seized the opportunity provided by the house to usurp the position of the sub-chiefs in Bafut. Kwifor members installed themselves within the power system as unbending political allies of the Fon. They did all things in his name and no other person. Kwifor members projected the image of the Fon and his authority in the entire Bafut land. In return, they were compensated with higher positions in the political set up. While the authority of the occupant of the throne grew stronger that of his rivals dwindled. This accounts for the reason why at the inception of colonialism, the colonial masters met only one leader who completely held sway over the people in the area. The British administrators in Bamenda remarked that the only leader of substance and authority over the people was the Fon of tikar origin. In this light, they conferred colonial authority to him by making him paramount Fon of Bafut, President of the Native Court and administration in Bafut Native Authority Area (SENA). He was the only leader to fly the Union jack over his palace and to own the portrait of King Charles VI. A blend of colonial and traditional authority made the Fon so full of power. All other leaders in Bafut were classified as persona non grata until 1977 when the Cameroon government issued the Chieftaincy Decree classifying traditional leaders in Cameroon (Official Gazette of the United Republic of Cameroon, July 15, 1972). 
In fact, the Village heads (chiefs) in Bafut had over the years accused British colonial authorities for assisting the Fon to usurp their powers and extend his rule over their people. The British from the outset made their point clear as far as issues of power politics were concerned. Using history and evidence from Hawkesworth's Intelligence Report on Bafut written in 1926, the British argued that they met a society already existing. In this society, people of Widikum migration existed. They were conquered by the Fon of Bafut's tikar ancestors not long after the tikar invasion some 150 years ago. Up to 1948, the leaders of the Widikum groups lived not as independent village heads but as sub-chiefs of Bafut. They paid tributes to the tikar Fon as a sign of their respect to his superior position and authority. It was common knowledge that the conquered vassals of the Bamenda Fons have always paid tribute and rendered services though the details of these tributes and services are nowhere officially recorded. The Widikum sub-chiefs and their people had never contested the right of the Fon to receive tribute or to be independent until 1948. In conclusion, the The Acting Resident for Bamenda Province said: "It would be unwise to take any administrative decision... in the absence of any evidence that the Fon seeks to impose harsh and unbearable rule and tributes on his sub-chiefs. Where there is any dispute over the customary rights and duties of sub-chief or his people, those disputes can best be determine in a court of law (Acting Resident, personal communication, 1954).

The British administrators spoke as people who have built empires (all over the world) through conquest and thus understood the nature and practice of power and authority in such lands. The court of law referred to was the Native Court instituted by the British to uphold the native laws and customs of the people so that indirect rule can succeed. The Fon of Bafut was the President of the Bafut Native Court and it was obvious that he could not take a decision against himself or permit that his authority be challenged by whosoever. In 1963 the Fon made it clear to the Senior Divisional Officer (SD0) for Bamenda Division that: "The laws that bind Bafut people are one and do not exempt parts of the land that will in turn exempt Bugree, a quarter in Bafut. These people are in my land they want to be set free... I should make a boundary in my land for them? ... this matter ... is really a painful wound in my heart now and can only be healed by a better step" (Achirimbi II, personal communication, 1966).

The declaration and request of the Fon took the West Cameroon Government authorities to task, obliging them to declare their position concerning the power wangles and authority in Bafut. In the matter of the Bafut- Banji dispute, the SDO for Bamenda declared:

Banji people are of widikum origin. They are amongst the widikum people who were conquered by Bafut in the past, and although in reality a quarter of Bafut, Banji is regarded as a village in so far as certain customs are concerned by courtesy of the Fon. But all quarters of Bafut farm widely throughout the area. They do not stick to accurately demarcated enclaves, and they have not got 
boundaries within Bafut. This suits all the quarters except Banji. Banji would like a boundary, but it would be unwise to agree to this. It would lead in due course to an attempt to set up a separate village with a 'village head' who would want to regard himself as an equal to the Fon. Although this dispute over headship has been reported to me, I tend to believe it falls within the terms of the recognition of Chief's Ordinance (SDO for Bamenda, personal communication, 1966).

From the declaration of the SDO, we observed that both colonial and West Cameroon government authorities used conquest to justify the powers and authority they invested in the Fon of Bafut at the detriment of other leaders in the area. This brought to question the legality of the conquest syndrome as an instrument of fonship and power politics in Bafut. It was in this light that an investigation was made on the mechanism of conquest put in place (from inception) by the tikar leader and his people.

According to Warnier, fonship and power was influenced by conquest and local enclosure system designed by the central palace authority at Bujong. Enclosures were effected in the mbunti region (lower Bafut) during the last third of the $19^{\text {th }}$ Century. Here, the assimilation of migrants and favourable matrimonial balance occurred. Bafut men and descendants of the royal family got married to women from the mbunti area. They also occupied and owned large farm lands in the area (1985). In the $19^{\text {th }}$ century, the Fon of Bafut effected an internal territorial reorganisation which was to permit a smooth extension of his authority in the mbunti area. The Fon divided Bafut into two areas of jurisdiction or territorial units. One was to be administered by kwifor and the other by takumbeng. Hence Bafut people had to become acquainted with appellations like akoohkwifor (kwifor's bush) and akoohtakumbeng (takumbeng's bush). These palace institutions took over the role which quarter heads, lineage heads and village chiefs played in territorial administration. Anybody who was interested in territorial administration had to belong either to kwifor or takumbeng. It was in this light that quarter heads who had not yet attained the rank of nkumkwifor, (kwifor noble) precipitated the payment of his dues at the central palace to gain promotion and be part of the system. Here, administrative issues of the fondom were decided by kwifor and takumbeng inside the palace and nowhere else. This was a ploy to canalise all territorial powers in the entire fondom and place under the control of the Fon. Some sub-chiefs opposed the arrangement because they felt that the business of territorial administration was their inalienable right. They argued that they brought their peoples into Bafut and therefore cannot afford to have their authority stripped over them. The result of this revolt is not our focus in this paper. What is of interest to us are the complex political issues that provoked the reform.

The Fon and his palace authorities wanted to ensure a steady flow and supply of tributes to the palace from all the territorial units that make up the fondom. In the case of lower Bafut, most of the Bafut wars were directed towards the widikum migrant groups in this 
area. The tikar leaders made this area their tribute zone with the obligation to supply the central palace (on annual basis) with palm oil, ivory, smoked fish and bush meat. War captives from this region became nchindas (servants) at the royal court of the Fon. Most of this area constitutes the Bafut forest with wild game of various types. The Fon of Bafut had declared this forest reserved for royal use only. By this no other person had the right to exploit the resources in this forest for personal use. The felling down of trees and the hunting of animals in this forest were to be authorised by the Fon and must be done in his name. Any animal caught in this forest must be taken to the central palace at Bujong. This was native law and custom, and anybody (irrespective of who you are) who disobeyed it committed an affront against the authority of the Fon. History tells of hunters and chiefs who attempted to violate this custom and were severely sanctioned by the central palace authorities (Ngwa, 2010). The fear to be sanctioned permitted the power and authority of the Fon to be respected throughout Bafut. It also permitted peace to reign until 1948 when colonial rule polluted the traditional set up and many sub-chiefs induced their people to violate the custom by refusing to tender tributes of agricultural products and animals to the Fon.

Furthermore, fonship and power politics were intricately linked to the economic set up in the area. The economy was fuelled by the exchange of primary products and farm produce. Trade brought the ntare people, the mumalaa and mbunti people together. Each group or people brought what was best produced in their zone for exchange at a central point in mumalaa. The expansion of trade necessitated the creation of a market which was eventually located near the palace and named after the Fon (mutaah mfor meaning, Fon's market). It operated on every eighth day of the week following the traditional calendar. The central palace used the market to enforce its authority over the entire fondom. On market days, instructions were given to the Bafut community between 12 noon and $1 \mathrm{pm}$. Here, the mabooh kwifor accompanied by top ranking nobles and kingmakers of the house, led a procession to the market centre (Ritzenthaler \& Ritzenthaler, 1962). The talking drum placed at the market summoned everybody to stop all other activities and listened to kwifor. All instructions and announcements were made in the name of the Fon and the ancestral kings that have passed on before. At the end of the announcements, kwifor instructed those present to take home the news and inform those who were not present so that they can together execute. Defaulters were warned in advance of the pending doom or sanction that awaits them at the central palace. No other leader in Bafut had the opportunity to have a market that assembled the entire Bafut population on one spot as was the case here. The Fon's market thus became an instrument of power politics in the hands of the central palace. Through it, the power and authority of the Fon was felt in all the corners of Bafut. During the reign of Achrimbi II, the hearts of all animals slaughtered in the market were taken to the palace as tribute to the Fon (Christina Lum Aboh, personal Communication, January $6,1998)$. In the wake of conflict between the Fon and his sub-chiefs in the 1980s and 
90s, the chiefs asked their people to boycott the Fon's market at mumalaa. The reason was hardly understood by many. It was because the market was a political instrument manned and used by the central palace to do its political bidding.

Also in recent times, the sub-chiefs attempted to destabilise the fondom by fanning secessionist struggles to break away from the main set up (society) and establish autonomous chiefdoms in Bafut. The peoples on their part developed strong loyalties and attachments to their leaders. They revived old traditional practices and customs of origin which had long been suppressed by the ruling dynasty at Bujong. When the Chieftaincy decree was promulgated in 1977, four years after, some of the village heads (sub-chiefs) were made second class chiefs within the Bafut fondom. This was interpreted by the chiefs (batangcho) concerned as a government legalisation of the struggle for secession and full autonomy which they began in 1948. In this light, the batangcho challenged the Fon's authority through the violation of native laws and customs related to his rights and attributes. They rejected the traditional title of atangcho and adopted for themselves the title of fon. The authority of the Fon over the sub-chiefdoms began to dwindle.

In the 1940s, Fon Achirimbi II was supported by the British colonial administrators in Bamenda to wade off the balkanisation traits orchestrated by the chiefs of Obang, Banji, Otang and Bawum. Achirimbi was categorical that any chief who wished to declare his independence from Bafut should leave or do so somewhere else and not on Bafut soil. As long as they continued to live in Bafut, they must recognise the superior position of the Fon and respect his authority. As mentioned earlier, the British colonial authorities validated the declaration of the Fon ${ }^{1}$. When Abumbi II took over the throne in 1968, the batangcho (sub-chiefs) took advantage of his youthfulness to continue their secessionist struggle. Abumbi drew the attention of the chiefs to his late father's declaration and went further to state that his forefathers had sacrificed arms and people to provide security for the entire Bafut fondom. They liberated the land from neighbouring occupations which sub-chiefs like Ntoh, wanki and Talah Banji were responsible. Within the fondom, instability reigns due to turmoil caused by these sub-chiefs. They provoke situations which they themselves are unable to resolve. Such problems had reduced them to lackeys - a feat they have refused to recognise. Abumbi insisted that the subchiefs must accept their subordinate position in Bafut. To match words with action, the central palace authorities embarked on cracking down the authority of the sub-chiefs through the appointment of third class chiefs with equal traditional status, functions and attributes to those of the second class chiefs. The direct blood brothers of some of the chiefs were appointed by the Fon (as third class chiefs) with the mission to undercut the authority of the sub-chiefs (batangcho) in their villages. By this, the Fon's authority

1 See the declarations of the Colonial and West Cameroon government authorities in pp. 18-20 of this paper. 
was enhanced over the fondom though within the context of political conflicts. Peace was also maintained and the unity of the diverse people of Bafut was kept intact.

\section{Conclusion}

We set out to investigate on fonship and power politics in Bafut. We were particularly attracted by the fact that in spite the diversity of the people in the area and in spite of the political wrangles amongst the leaders the society is held intact under the supreme control and leadership of the Fon at Bujong. This caused us to dig into the mechanisms and political manoeuvres that were put in place to enhance the authority of the Fon in the heterogeneous society and, also, to see how the methods employed were able to manage or resolve conflicts amongst the leaders in a bid to maintain peace in the fondom. We saw a number of strategies which enabled peace and fonship to triumph in Bafut. Most of them were embellished in the traditions and customs of the people. We saw a ruling dynasty suffocated by power tussle thus making the political environment and system complex. Yet the system was able to contain pressure from opponents and detractors of the throne for decades past. We understood that conflict is a characteristic of power politics. No political system is free of conflict for there shall always be ambitious detractors with vested interest. Thus, the ability of the Fon to hold Bafut together under his control and ensure peace, makes the fondom a perfect example of unity in diversity and master of the politics of coexistence. This distinguishes Bafut from the other fondoms of the Grassfields ${ }^{2}$, thus suggesting that power is not universal. It is exercised within a given context and with its own peculiarities. For fonship to survive in a boiling society (as Bafut) it requires a leader with exceptional political skills and mechanisms. The rule of the Bafut Fons (from inception) has proven that power is not given to who wants but to who can. The existence of peace does not negate conflict. It all depends on how the leader manages the crises according to the methods or instruments at his disposal.

\section{References}

1. Aletum, M. T. (1974). Political Conflict within the Traditional and Modern Institutions of the Bafut-Cameroon. Louvain: Vander.

2. Brown, P. (1951). Pattern of Authority in West Africa. Africa, 21(4), 254-288.

3. Chilver, E. M., \& Kaberry, P. M. (1959). Traditional Politics in Nsaw. Africa, 29(4), 366383.

4. Chilver, E. M., \& Kaberry, P. M. (1961). An Outline of the Traditional Political System of Bali-Nyonga. Africa, 31(4), 362-372.

5. Chilver, E. M., \& Kaberry, P. M. (1963). Traditional Government in Bafut. The Nigerian Field, 28, 4-30.

2 Bafut is the only Grassfield First Class Fondom with eight recognized Second Class Chiefdoms within it. 
6. Chilver, E. M., \& Kaberry, P. M. (1967). Traditional Bamenda : The Pre-colonial History and Ethnography of the Bamenda Grassfields. Buea: Government Printer.

7. Chilver, E. M., \& Kaberry, P. M. (1970). Chronology of the Bamenda Grassfields. Journal of African History, 11(2), 249-257.

8. Cullock, M. M., Littlewood, M., \& Dugast, I. (1954). Peoples of the Central Cameroons. London: Oxford University Press.

9. Engard, R. K. (1988). Myth and Political Economy in Bafut (Cameroon): The Structural History of an African Kingdom. Paideuma, 34, 50-89.

10. Engard, R. K. (1989). Dance and Power in Bafut (Cameroon). In W. Arens and I. Karp (Eds.), Creativity of Power: Essays in Ritual and Authority in African Societies (pp. 129162). Washington: Smithsonian Institute Press.

11. Ewusi, N. M. (1978). Palace Organisation in Bafut Cameroon. B.A. Long Essay submitted to the University of Ife, Ile-Ife.

12. Hawkesworth, E. G. (1926). Assessment Report on the Bafut Tribal Area of the Bamenda Division, NAB.

13. Hook, R. J. (1934). An Intelligence Report on the Associated Village Groups Occupying Bafut Native Authority Area of the Bamenda Division of Cameroons Province.

14. Ikime, 0. (1965). Traditional System of Government and Justice among the Urhobo and Isoko of Delta Province, Nigeria. The Nigerian Journal of Economic and Social Studies, $7(3), 281-107$.

15. Jeffreys, M. D. W. (1962). Traditional Sources Prior to 1890 for the Grassfield Bali of Northwest Cameron. Africa Und Ubersee, 46(3), 168-169.

16. Mair, L. (1977). African Kingdoms. Oxford: Clarendon Press.

17. Ngwa, D. F. (1996). The Impact of British Colonial Rule on the Traditional Society of the Bafut Fondom: 1922-1961. B.A. Long Essay submitted to the University of Buea, Cameroon.

18. Ngwa, D. F. ( 1999). The 1968-69 Succession Conflict in the Bafut Kingdom. Unpublished M. A. Dissertation, University of Yaounde I, Cameroon.

19. Ngwa, D. F. (2010). Fon, Chiefs and People in Conflict in Bafut, North West Cameroon, 1900-1982. Unpublished PhD. Dissertation, University of Yaounde I, Cameroon.

20. Niba, M. L. (1999). Ethnic Tensions in the Bafut Kingdom of the Northwest Cameroon. Context: Journal of Social and cultural Studies, 3(2), 22-33.

21. Official Gazette of the United Republic of Cameroon. (1977). Decree No. 77/245 of 15 July 1972 relating to the Organization of Chieftaincies in Cameroon.

22. Ritzenthaler, R., \& Ritzenthaler, P. ( 1962). Cameroons Village: An Ethnography of the Bafut. Milwaukee: Public Museum.

23. Rowe, J. A. (1975). The Pattern of Political Administration in Pre-Colonial Buganda. In I. Abu- Lughod (Ed.), African Themes: Northwestern University studies in honor of Gwendolen M. Carter (pp. 63-132). Evanston: Program of African Studies, Northwestern University.

24. The Bafut Public Confessions and Reconciliation. (1996). Bamenda: Unique Printers. 
25. Tweed, A. E. (1926). Assessment Report on Moghamo and Ngemba Bamenda, NAB.

26. Vansina, J. (1962). A Comparison of African Kingdom. Africa, 32, 324-334.

27. Warnier, J. P. (1985). Echanges, Développement, et Hiérarchies dans le Bamenda précolonial (Cameroun). Stuttgart: Franz Steiner Verlag Weisbaden. 